\title{
有限要素法を用いた大規模空間吊り天井の脱落被害再現シミュレーション COLLAPSE SIMULATION OF WIDE-AREA SUSPENDED CEILING SYSTEM USING FINITE ELEMENT METHOD
}

\author{
磯部 大吾郎*, 藤 原嵩士 ${ }^{* *}$, 山下拓三***, 田川浩 之****, 佐々木 智大***** \\ Daigoro ISOBE, Takashi FUJIWARA, Takuzo YAMASHITA, \\ Hiroyuki TAGAWA and Tomohiro SASAKI
}

\begin{abstract}
In this paper, a numerical analysis to simulate the ceiling collapse in a full-scale gymnasium specimen, which was tested at the EDefense shaking table facility in 2014, was conducted. The numerical model consisted of steel structural frames and suspended ceilings were constructed. All the members were modeled using linear Timoshenko beam elements and the ASI-Gauss code was applied. The numerical result had shown the collapse of the ceilings progressed owing to the detachment of clips that connected the ceiling joists to the ceiling joist receivers, which eventually led to a large-scale collapse of the ceilings.
\end{abstract}

Keywords : Ceiling collapse, E-D efense, Gymnasium, Nonstructural component, ASI-Gauss technique, FEM 天井脱落, E一ディフェンス, 体育館, 非構造部材, ASI-Gauss 法, 有限要素法

\section{1.はじめに}

学校体育館に代表される大規模空間を有する屋内運動場等施設は, 災害時に避難施設としての役割を担っていることから，災害発生後 も使用可能であることや余震にも耐えうる施設であることが求めら れる。しかし，2011年 3 月 11 日の東北地方太平洋沖地震では最大 震度 7 の本震に加えて震度 6 以上の余震が複数回発生し, 天井や外 壁・内壁などの非構造部材や照明等の設備機器の脱落被害より避難 施設としての役割を果たさなかった事例が報告されている 1) (図 1 参照)。また一方， 2016 年 4 月 14 日の熊本地震では最大震度 7 の 前震の後, 4 月 16 日に最大震度 7 の本震が発生し, 前震で被害が軽

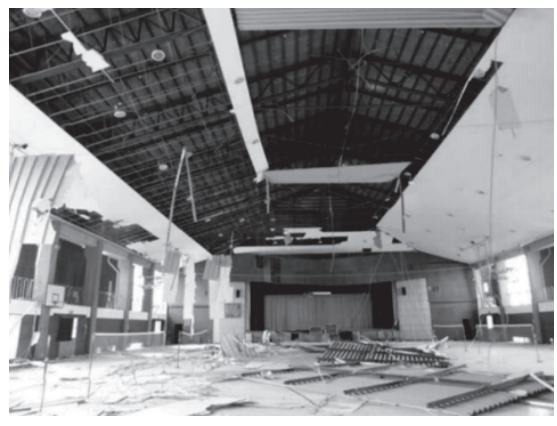

Fig. 1 Ceiling collapse occurred during 2011 Great East Japan Earthquake $^{1)}$
微であった, または, 確認されなかった場合でも, 本震で天井が落 下寸る等の大きな被害が発生するという, 連続地震により天井脱落 被害が拡大した事例が多く報告されている2)(図 2 参照).

東北地方太平洋沖地震以降, 天井落下報告を受け, 国土交通省で は 2013 年に建築基準法の改正 ${ }^{3)}$ と関連告示の制定 ${ }^{4)}$ を行い, 技術基 準 5)を 2014 年 4 月 1 日より施行している(以下，この技術基準を $\mathrm{H} 26$ 技術基準とする). $\mathrm{H} 26$ 技術基準では「6 m 超の高さにある, 水平投影面積 $200 \mathrm{~m}^{2}$ 超, 単位面積重量 $2 \mathrm{~kg} / \mathrm{m}^{2}$ 超の天井で, 人が日 常利用する場所に設置してあるもの」を「脱落によって重大な危害 を生ずるおそれがある天井」(「特定天井」とも略される)と定義し,

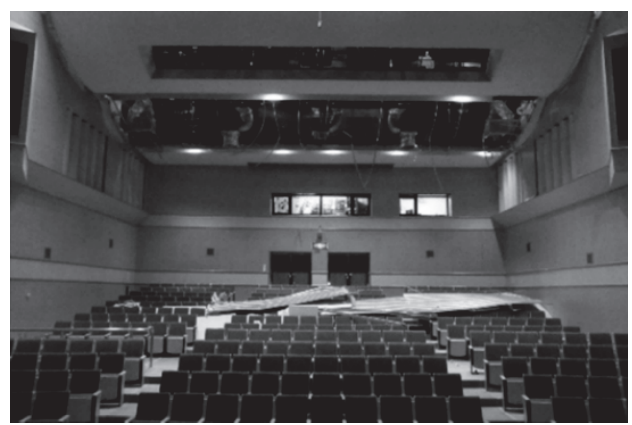

Fig. 2 Ceiling collapse occurred during 2016 Kumamoto Earthquake ${ }^{2)}$
* 筑波大学 教授 · 博士 (工学)

** 前 筑波大院生・修士 (工学) (現 日本サムスン(株)

*** 防災科学技術研究所 主任研究員 - 博士 (工学)

**** 武庫川女子大学 准教授. Ph.D.

***** 前防災科学技術研究所 主任研究員 · 博士 (工学) (現（株大林組）
Prof., Univ. of Tsukuba, Dr.Eng.

Former Grad. Student, Univ. of Tsukuba, M.Eng. (currently Samsung Japan Corporation) Chief Researcher, NIED, Dr.Eng.

Assoc. Prof., Mukogawa Women's Univ., Ph.D.

Former Chief Researcher, NIED, Dr.Eng. (currently Tech. Res. Inst. of Obayashi Co.) 


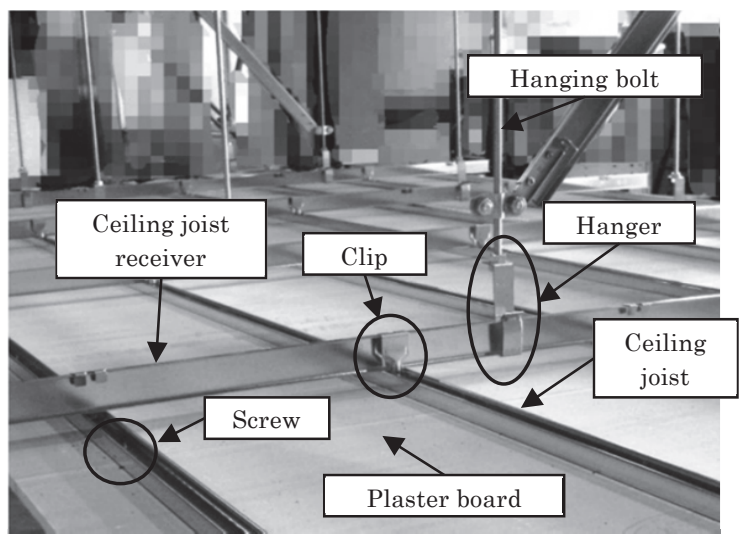

Fig. 3 Components of conventional type ceiling with steel furrings

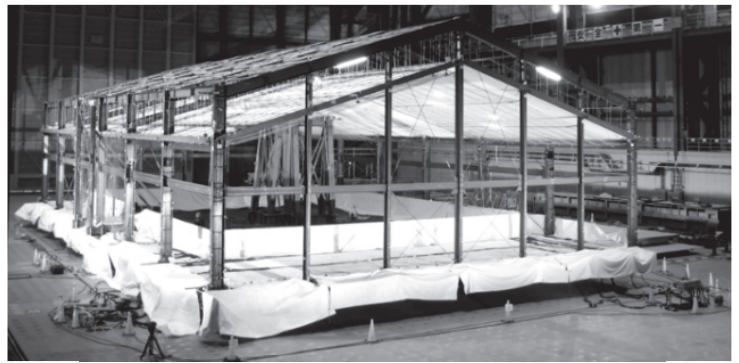

Fig. 4 Gymnasium specimen ${ }^{8}$

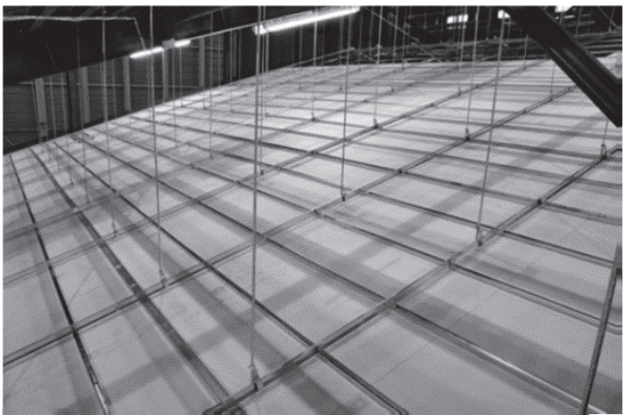

Fig. 5 Ceilings in the specimen ${ }^{8)}$

脱落防止対策を義務づけることとしている. 2015 年 4 月時点で公 立小中学校の内, 対策が未実施の吊り天井を有する屋内運動場等施 設は 4,849 棟（全棟数 33,392 棟の $14.5 \%$ ）存在しており 6 ), 耐震 化の遅れている地方公共団体に対しては文部科学大臣より耐震化を 進める書簡が発出されている。 また, 学校施設に耐震化ガイドブッ クを配布し，天井の定期的な点検・対策を推進している 7).

これらの対策は, 地震後の被災調査から推定された破壊メカニズ ムや天井要素の実験結果を根拠としている. しかしながら, 天井要 素のみを取り出した実験のみでは脱落被害の再現は難しい, そこで, 天井の脱落メカニズムを明らかにするべく，2014 年 1 月に実大三 次元震動破壊実験施設（以下， E一ディフェンス）で学校体育館を 模擬した大空間を有する試験体に設置された吊り天井の脱落被害再 現実験が実施された ${ }^{8)}$. この実験により，天井の脱落メカニズムに ついて多くの有用な知見が得られた。しかし, 天井は様々な種類の 形状が存在するため，それぞれの場合での脱落メカニズムの解明が 望まれる，また，同一形状の天井においても，設備の干渉等の現場 毎に異なる特殊な環境が存在することから，実験の再現性を把握す
るため, 結果のばらつき評価も必要になる，そのためには，様々な 条件での検証や同一対象でも複数回の検証が必要となるが, 大規模 実験のみではコスト面で問題があり, その代替, 補完手法として数 值シミュレーションの果たす役割は大きい。 また，今後危惧される 連続地震に備え, 連続地震解析による天井の脱落メカニズムを検証 することは重要である.

そこで本稿では, 地震時の体育館内における天井落下現象を再現 するシミュレーション技術を構築し, 上述の吊り天井の脱落被害実 験の再現解析を試みた。解析には, 地震動, 弾塑性, 破断を含む非 線形性の高い解析でも安定して行える ASI-Gauss 法 9)を用いた. 実 験では吊りボルトやブレースの座屈現象が確認されたため, 体育館 構造躯体に未対策天井を取り付けた試験体を対象とし, 上記部材の 座屈現象を再現可能とするようなモデル化を施し, 地震応答解析を 実施した。実験と同様に地震波形を連続的に 2 回入力し, その前後 の被害の推移について検証した.

以下に本論文の構成を記す。第 2 章では試験体に使用された吊り 天井の構造について述心゙，第 3 章では各構成要素の脱落条件につい て説明する. 続いて第 4 章では解析モデルおよび解析条件, 第 5 章 では実験と解析を比較・検証した結果について考察する. 最後の第 6 章では結論を述べる。

\section{2. 吊り天井の構造}

一般に学校体育館等に用いられる天井は, 鋼製下地在来工法天井 と呼ばれる. 図 3 に示すように, 天井の下地材は吊りボルト, 野縁 受け, 野縁, せっこうボードで構成されており, それぞれは八ンガ 一, クリップ, ビス, 野縁・野縁受けジョイントによって接合され る. 具体的には, ハンガーは吊りボルトと野縁受け, クリップは野 縁受けと野縁，ビスは野縁とせっこうボード，ジョイントは野縁ま

Table 1 Spec of non-seismic ceilings used in the experiment ${ }^{8)}$

\begin{tabular}{|c|c|}
\hline Item & Spec \\
\hline Horizontal design load & None \\
\hline Horizontally projected area & $19.0 \times 30.0[\mathrm{~m}]\left(570\left[\mathrm{~m}^{2}\right]\right)$ \\
\hline Total area & $625\left[\mathrm{~m}^{2}\right]$ \\
\hline Mass of ceiling per area & $13.1\left[\mathrm{~kg} / \mathrm{m}^{2}\right]$ \\
\hline Clearance & None \\
\hline Hanger length & $1,500[\mathrm{~mm}]$ \\
\hline Hanger interval & $1,147 \times 1,000[\mathrm{~mm}]$ \\
\hline Hanging bolt & W3/8 hanging bolt \\
\hline Hanger & $\begin{array}{l}\text { Free hanger } \\
\text { (permissible substitute of } \\
\text { JIS standard) }\end{array}$ \\
\hline Single ceiling joist & JIS19 type @364 [mm] \\
\hline Double ceiling joist & JIS19 type @1,820 [mm] \\
\hline Ceiling joist receiver & JIS19 type @1,000 [mm] \\
\hline Clip & One-touch clip for JIS19 type \\
\hline Brace & None \\
\hline Finishing material & $\begin{array}{l}\text { Plaster board } 9.5[\mathrm{~mm}] \\
\text { +Rockwool absorber } 9[\mathrm{~mm}] \\
\quad \text { Screw } \varphi 3.5[\mathrm{~mm}]\end{array}$ \\
\hline
\end{tabular}




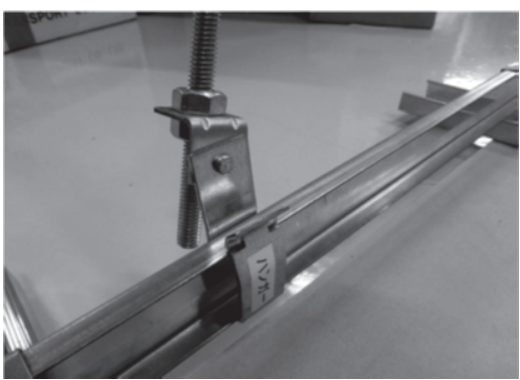

(a) Ceiling joist receiver and hanger

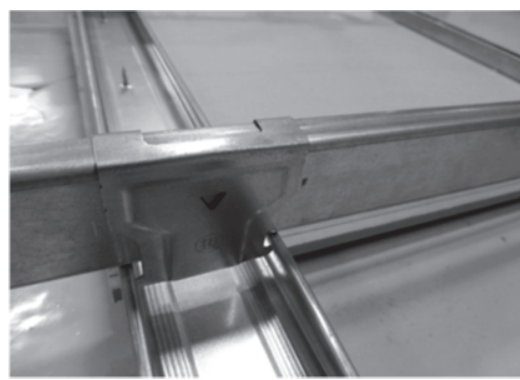

(b) Double ceiling joist and double clip

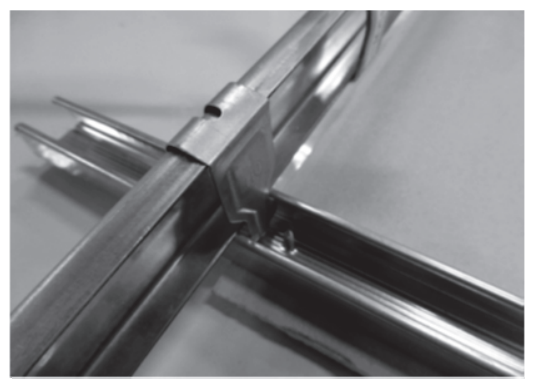

(c) Single ceiling joist and single clip

Fig. 6 Base materials used for non-seismic ceilings ${ }^{8)}$

Table 2 Sizes and materials of the components ${ }^{10}$ )

\begin{tabular}{|l|l|l|}
\hline \multicolumn{1}{|c|}{ Name } & \multicolumn{1}{c|}{ Size $[\mathrm{mm}]$} & \multicolumn{1}{c|}{ Material } \\
\hline Hanging bolt & $\varphi 9$ & JIS G 3101 \\
\hline Ceiling joist receiver & $38 \times 12 \times 1.2$ & JIS G 3302 \\
\hline Single ceiling joist & $19 \times 25 \times 0.5$ & JIS G 3302 \\
\hline Double ceiling joist & $19 \times 50 \times 0.5$ & JIS G 3302 \\
\hline Clip & t0.6 & JIS G 3302 \\
\hline
\end{tabular}

たは野縁受け同士を接合する。

Eーディフェンスの実験で使用された試験体 8)を図 4 に示す.こ の試験体には, 図 5 に示すような未対策天井が施工されている。そ の主な仕様を表 1 に示す。天井の勾配は屋根の勾配と同一の 10:3 となっており, 天井の水平投影面積は $570 \mathrm{~m}^{2}$, 見付面積は $625 \mathrm{~m}^{2}$ である。また，天井単位面積質量は $13.1 \mathrm{~kg} / \mathrm{m}^{2}$ である。天井と構造 躯体の間にクリアランスは無く，試験体側面梁 $\mathrm{H} 200 \times 200 \times 8 \times 12$ を内壁と見なし，これに対し，仕上げ材を隙間なく敷き詰めて天井 を仕上げている。下地材には図 6 に示す JIS 規格 19 形天井下地材 を使用している．その寸法および材質を表 2 に示す ${ }^{10)}$. クリップに は施工が容易なワンタッチクリップが採用されており, 背掛け, 腹 掛けを交互に並べるように取り付けられている。

\section{3. 脱落条件}

天井の接合部材であるハンガー，クリップ，ビス，野縁ジョイン 卜には次に示す脱落条件を導入し，設定した条件を満たした際にそ の要素を破断させることで脱落を再現した，脱落条件には，要素内

Table 3 Main spec of steel gymnasium specimen ${ }^{8)}$

\begin{tabular}{|c|c|}
\hline Item & Spec \\
\hline Structure and floors & Steel frame, single floor \\
\hline Weight & 208.2 ton \\
\hline Max. height & $9.090 \mathrm{~m}$ \\
\hline Horizontal sizes & $30.0 \mathrm{~m} \times 18.6 \mathrm{~m}(6 \times 6$ spans $)$ \\
\hline Column & $\mathrm{H} 400 \times 200 \times 8 \times 13(\mathrm{SS} 400)$ \\
\hline Column at end panel & $\begin{array}{l}\mathrm{H} 250 \times 125 \times 6 \times 9(\mathrm{SS} 400) \\
\quad \mathrm{H} 300 \times 150 \times 6.5 \times 9(\mathrm{SS} 400)\end{array}$ \\
\hline Girder & $\mathrm{H} 400 \times 200 \times 8 \times 13(\mathrm{SS} 400)$ \\
\hline Binder & $\mathrm{H} 248 \times 124 \times 5 \times 8(\mathrm{SS} 400)$ \\
\hline Vertical brace & M20, M27(SNR400B) \\
\hline Horizontal brace & M16, M30(SNR400B) \\
\hline
\end{tabular}

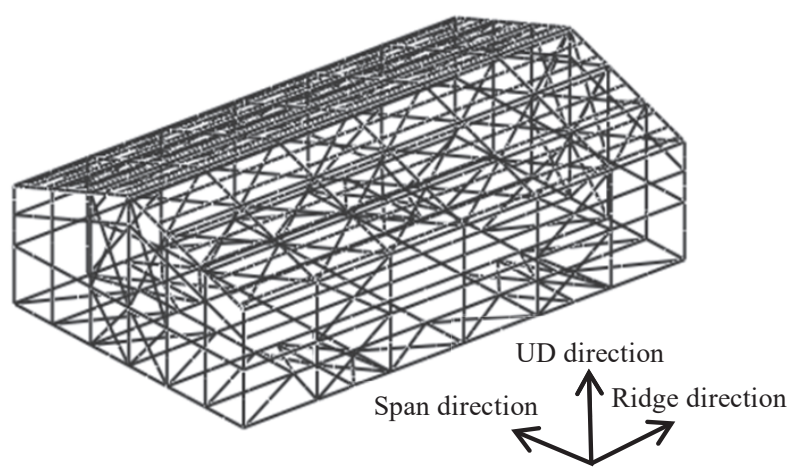

Fig. 7 Structural frame model of gymnasium

断面力により判定する荷重条件と, 要素の変形により判定する変位 条件の 2 種類を用いた。

ハンガーの脱落条件には荷重条件を設定し，鉛直下向きに引張力 $2.8 \mathrm{kN}$ が作用した場合に脱落を判定した ${ }^{8)}$.

クリップの脱落条件には全て荷重条件を設定し，シングルクリッ プの腹掛けの場合は鉛直下向きに引張力 $0.35 \mathrm{kN}$, 背掛けの場合は 引張力 $0.70 \mathrm{kN}$ ，ダブルクリップの場合は背掛け腹掛け共に引張力 $0.80 \mathrm{kN}$ が加わった際に脱落を判定した ${ }^{8)}$. なお，後述のように 1 つのクリップは 2 つの要素で表現している．1つの要素が負担する 荷重はクリップ単体の半分になるため, 解析に導入する荷重条件も 上記の值の半分の値にした.

ビスに関しては,引張とせん断方向に脱落条件を設けた.ここで, ビスの要素試験では, 最大荷重が加えられた後にしばらく変形して からビスが抜けたため, 荷重条件に変位条件を加えた. 具体的には, ビスの引張方向に対しては，軸方向に $0.40 \mathrm{kN}$ の引張力が作用した 後, 軸方向に $3 \mathrm{~mm}$ 変位した場合に脱落を判定した ${ }^{11)}$. また, せん 断方向に対しては， $0.30 \mathrm{kN}$ のせん断力が作用した後，その方向に $18 \mathrm{~mm}$ 変位した際に脱落を判定することとした ${ }^{12)}$. なお，本解析 モデルでは, 要素分割数を極力減らしビスの本数を試験体の 3 分の 1 に縮約したため, 脱落条件としては 3 倍の耐力を設定した.

野縁ジョイントの脱落条件には荷重条件を設定した．野縁ジョイ ントについては有用な要素試験結果が得られていないため, ここで は野縁ジョイント 1 本当たりが負担する天井の重量 $0.28 \mathrm{kN}$ に安全 率 2 を掛けた $0.56 \mathrm{kN}$ が要素に引張力として加わった場合に脱落す ると仮定した。

\section{4. 解析モデルおよび解析条件}

体育館の構造躯体モデルは， $\mathrm{E}$ 一ディフェンスの実験で使用され 


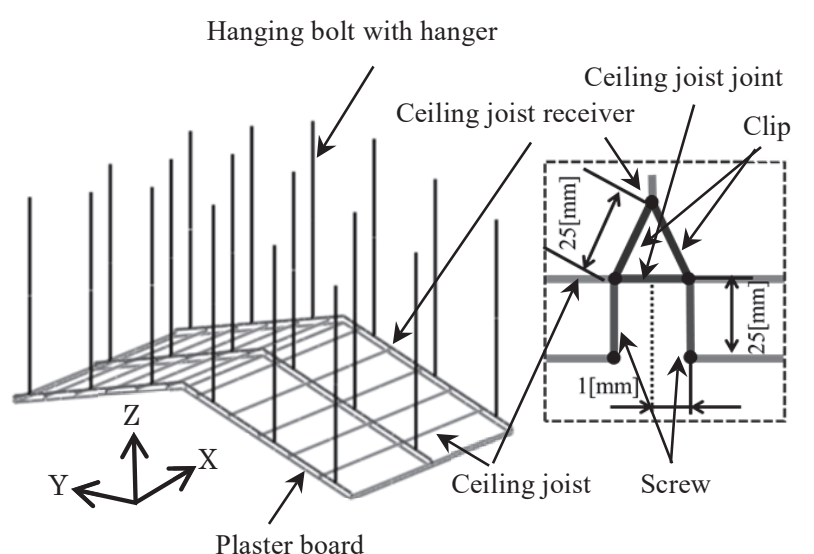

Fig. 8 An outline of suspended ceiling model

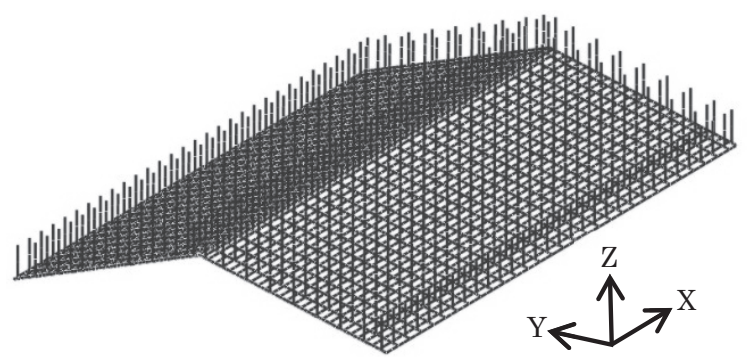

Fig. 9 Full model of suspended ceilings

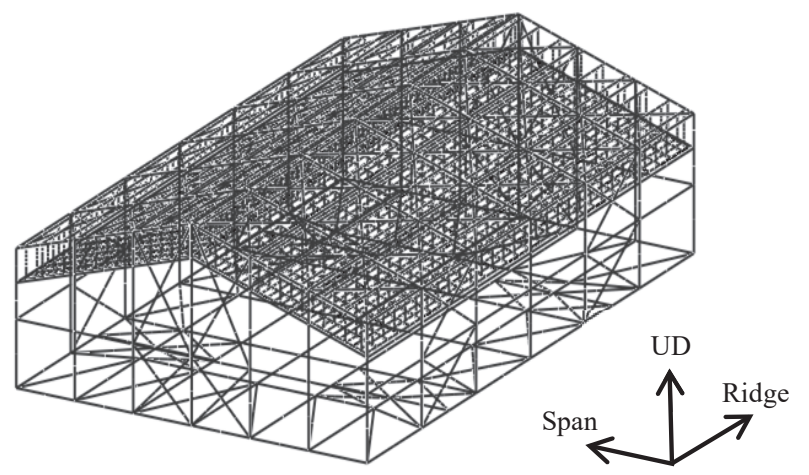

Fig. 10 Gymnasium model with suspended ceilings

た実大体育館試験体の図面 8 亿基づき作成した。表 3 に構造躯体の 主な仕様を示寸，構造躯体は鋼構造の平屋建てで，平面寸法は桁行 $30.0 \mathrm{~m} \times$ 梁間 $18.6 \mathrm{~m}$, 前述のように屋根勾配は 10:3 で最大高さは $9.09 \mathrm{~m}$ の大空間を有する構造となっている．解析には ASI-Gauss 法 9)を用いたため, 全ての構造部材を基本的には 1 部材当り 2 つの 線形チモシェンコはり要素でモデル化した，大梁，小梁およびブレ ースは両端がピン接合であるため，部材両端に曲剬性を低下させ た微小要素(長さ:他要素の断面長の $1 / 2$, 剛性: 部材剛性の 1/10,000) を追加した. また, ブレースは座屈現象を再現可能とするため 10 要 素分割 (通常要素 8 つ前述の微小要素 2 つ) とした. 大梁上に取 り付けた屋根面重量を模擬するための錘，キャットウォークは，重 量のみを考慮して大梁に密度として加えた，さらに，引き抜き力に よるアンカーボルトの伸びを考慮して，柱脚部には回転剛性を低下 させた微小要素を配した. 図 7 に構造躯体のみのモデル概形を示す.
次に，吊り天井を図 8 に示すようにモデル化した。モデル化した 部材は, 吊りボルト, 野縁受け, 野縁, せっこうボード, クリップ, ビス，野縁ジョイントである，吊りボルトの長さは $1,500 \mathrm{~mm}$, ク リップ, ビスの長さは $25 \mathrm{~mm}$, 野縁ジョイントの長さは $2 \mathrm{~mm}$ とし た。吊りボルトはハンガーと一体化してモデル化し，ピン接合およ び座屈を再現するため, 前述のように 10 要素分割とした。クリッ プは野縁受けから 2 つに分けて野縁に接続することで，クリップお よび野縁ジョイントが脱落した際に，野縁と一体化したせっこうボ ードがそれぞれ単体で落下寸る現象を再現可能とした．2つの要素

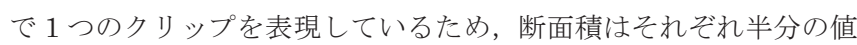
としている．また，せっこうボードを 1 枚ずつモデル化することに より，ビスが脱落した際のせっこうボード単体の局所落下を，さら にはせっこうボード間を $1 \mathrm{~mm}$ 離すことで，せっこうボード間の接 触を再現可能とした. せっこうボードはロックウール吸音板と一体 化してモデル化しており, 吸音板の重量を密度として加えている.

図 9 に吊り天井の全体モデルを示す. 全体の寸法は桁行 $29.6 \mathrm{~m} \times$ 梁間 $18.4 \mathrm{~m}$, 吊りボルトの間隔は桁行方向に $1,000 \mathrm{~mm}$, 梁間方向 に $1,147 \mathrm{~mm}$ （屋根面沿いに $1,200 \mathrm{~mm}$ ）である.

図 7 の構造躯体モデルと図 9 の吊り天井全体モデルを組み合わ せ, 図 10 に示す吊り天井付き体育館モデルを構築した. 全要素数 は 37,518 , 全節点数は 30,059 である. 自由振動解析より算出した 本モデルの固有周期は桁行方向が $0.334 \mathrm{~s}$ (実測 : $0.368 \mathrm{~s}$ ), 梁間方 向は $0.404 \mathrm{~s}$ (実測： $0.399 \mathrm{~s}$ ) であり, 試験体の固有周期と良好に 一致した。壁とせっこうボード間の接触を解析上で良好に再現する ために, 壁とせっこうボード間にも初期段階で $1 \mathrm{~mm}$ のクリアラン

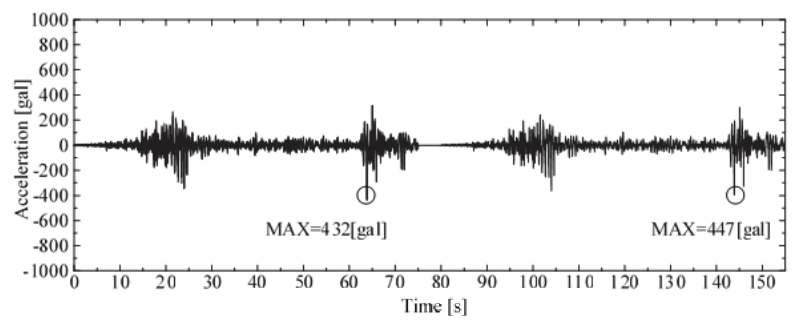

(a) Ridge direction

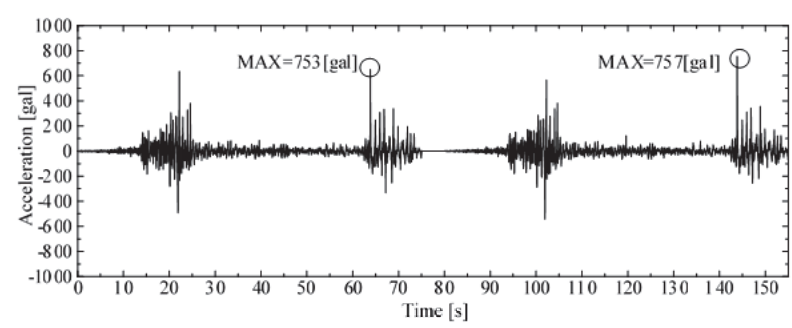

(b) Span direction

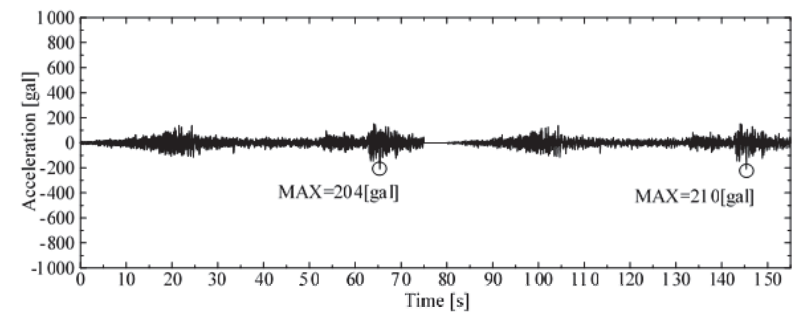

(c) UD direction

Fig. 11 Input wave (continuous excitation) 


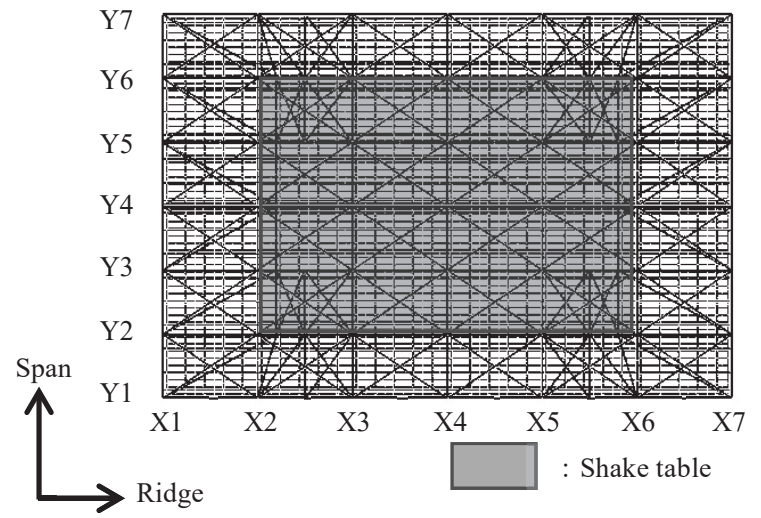

Fig. 12 Constraint area of base columns

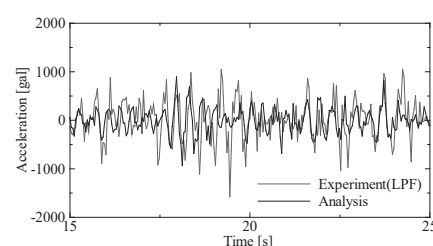

(a) $15-25 \mathrm{~s}$

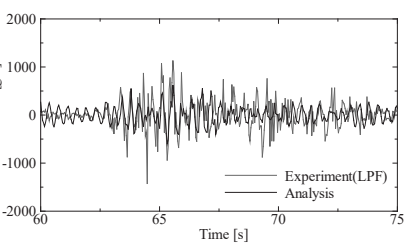

(b) $60-75 \mathrm{~s}$
Fig. 13 Response acceleration at roof top ( $1^{\text {st }}$ excitation, ridge direction)

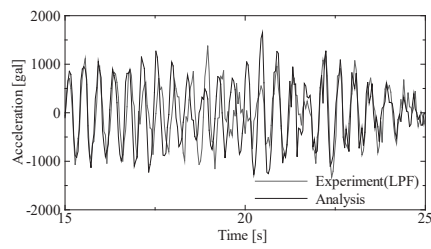

(a) $15-25 \mathrm{~s}$

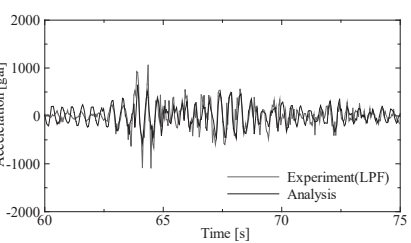

(b) $60-75 \mathrm{~s}$
Fig. 14 Response acceleration at roof top ( $1^{\text {st }}$ excitation, span direction)

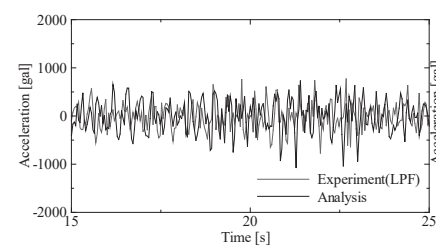

(a) $15-25 \mathrm{~s}$

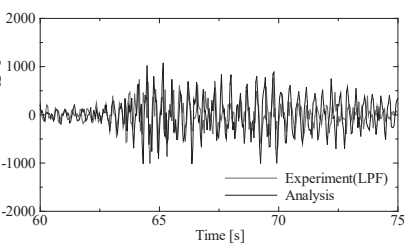

(b) $60-75 \mathrm{~s}$
Fig. 15 Response acceleration at roof top ( $1^{\text {st }}$ excitation, UD direction)

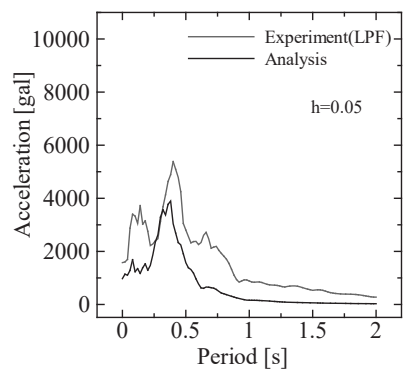

(a) Ridge direction

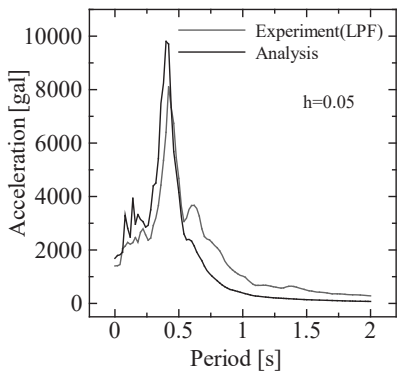

(b) Span direction

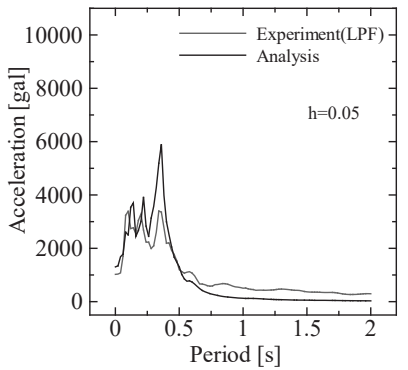

(c) UD direction

Fig. 16 Acceleration response spectrum ( $1^{\text {st }}$ excitation, 0-75 s)

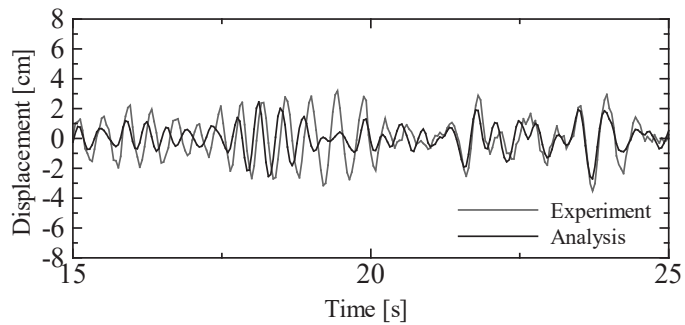

(a) $15-25 \mathrm{~s}$

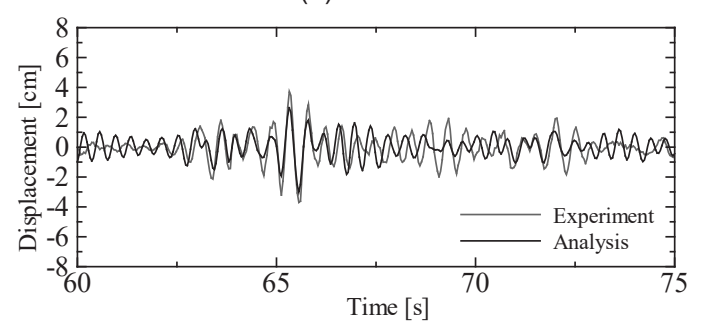

(b) $60-75 \mathrm{~s}$

Fig. 17 Response displacement ( $1^{\text {st }}$ excitation, ridge direction)

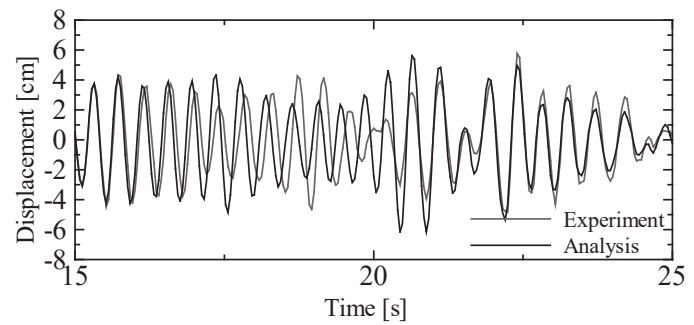

(a) $15-25 \mathrm{~s}$

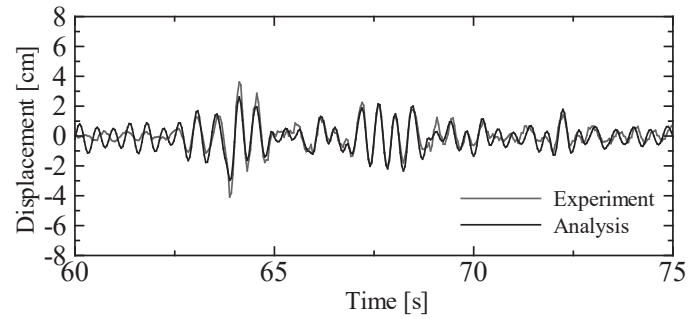

(b) $60-75 \mathrm{~s}$

Fig. 18 Response displacement ( $1^{\text {st }}$ excitation, span direction)

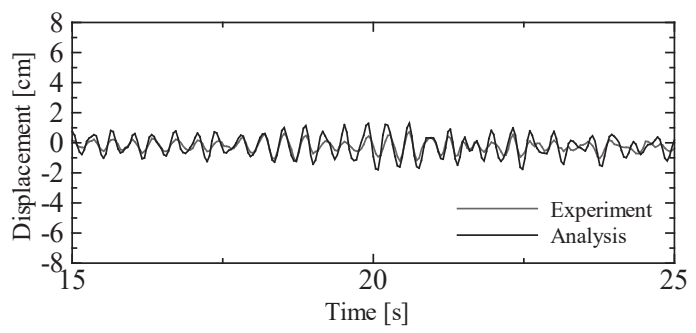

(a) $15-25 \mathrm{~s}$

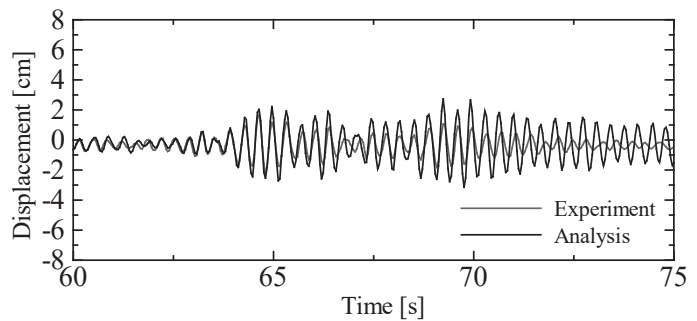

(b) $60-75 \mathrm{~s}$

Fig. 19 Response displacement ( $1^{\text {st }}$ excitation, UD direction) 

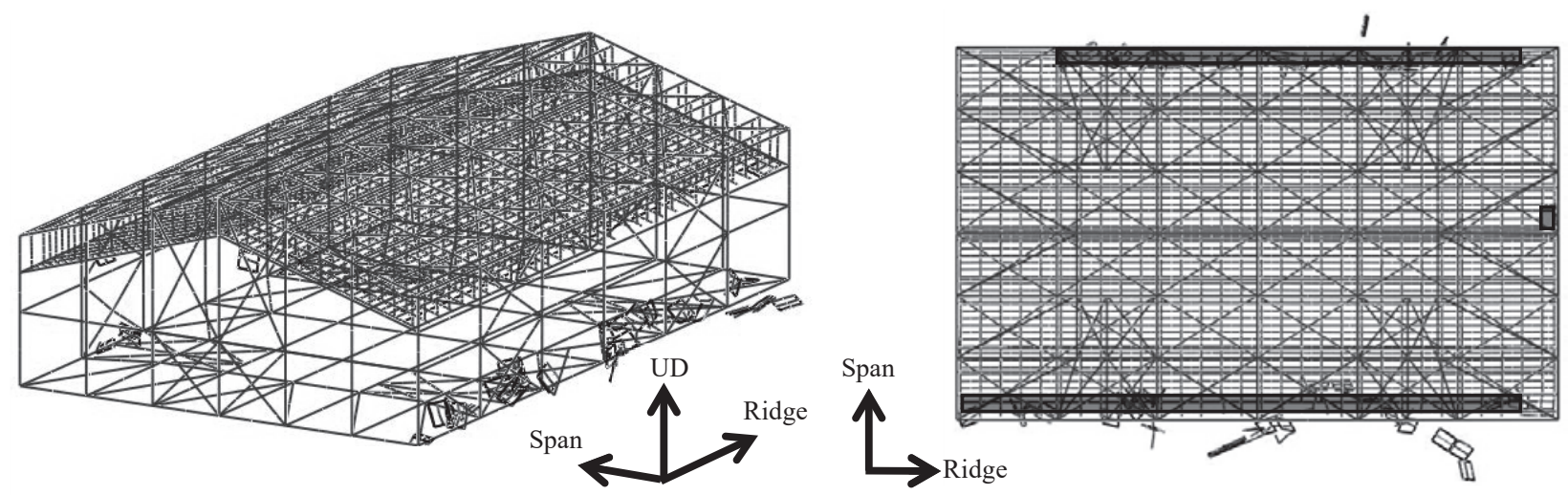

(a) After $1^{\text {st }}$ peak during $1^{\text {st }}$ excitation

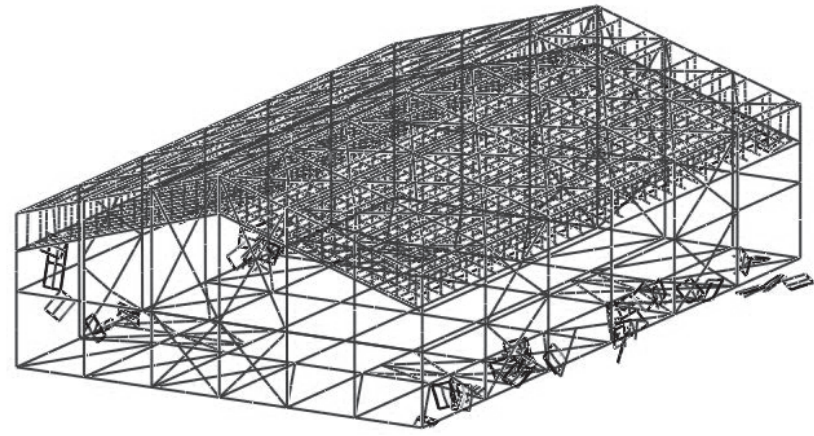

(b) After $2^{\text {nd }}$ peak during $1^{\text {st }}$ excitation
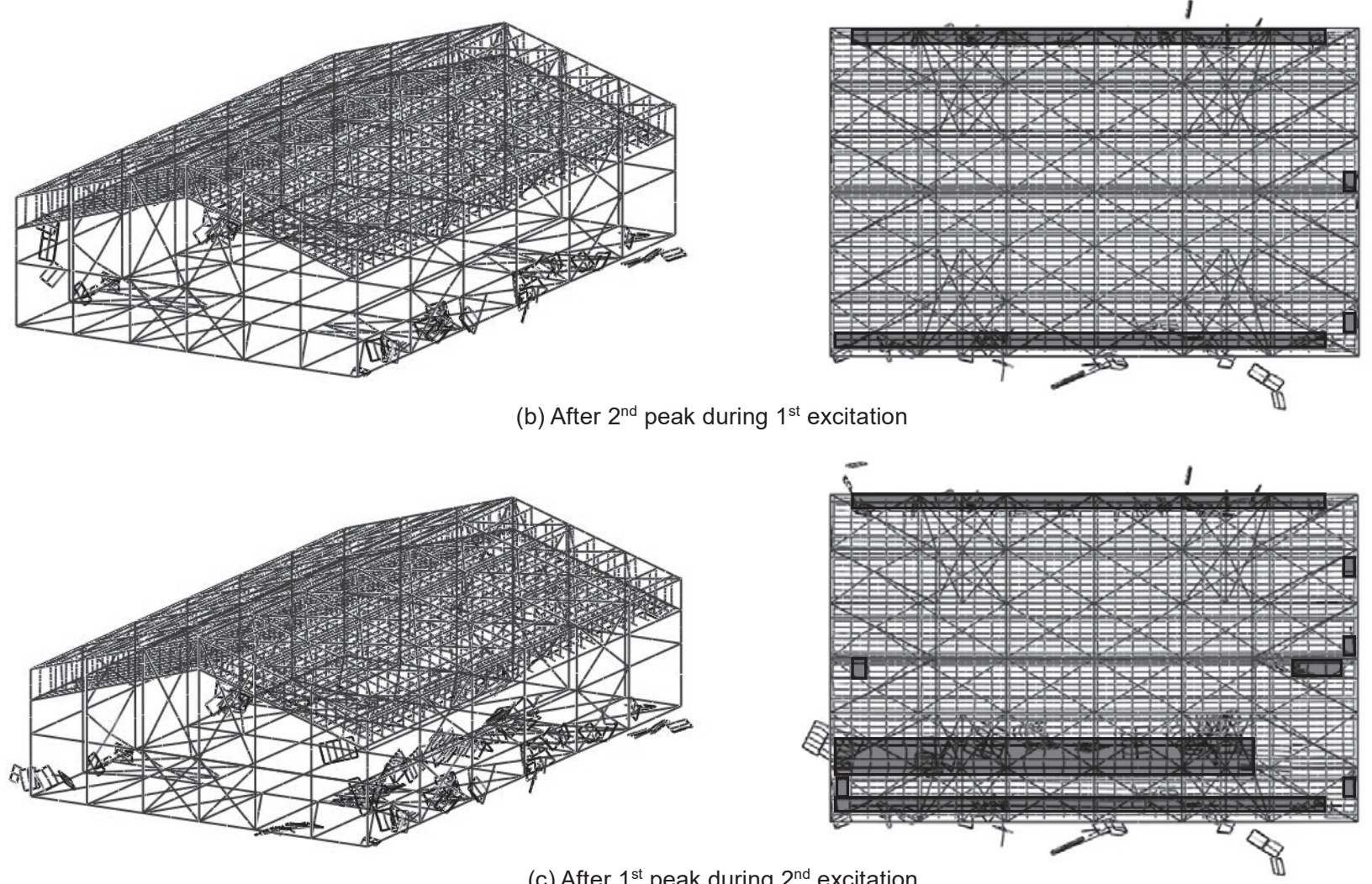

(c) After $1^{\text {st }}$ peak during $2^{\text {nd }}$ excitation
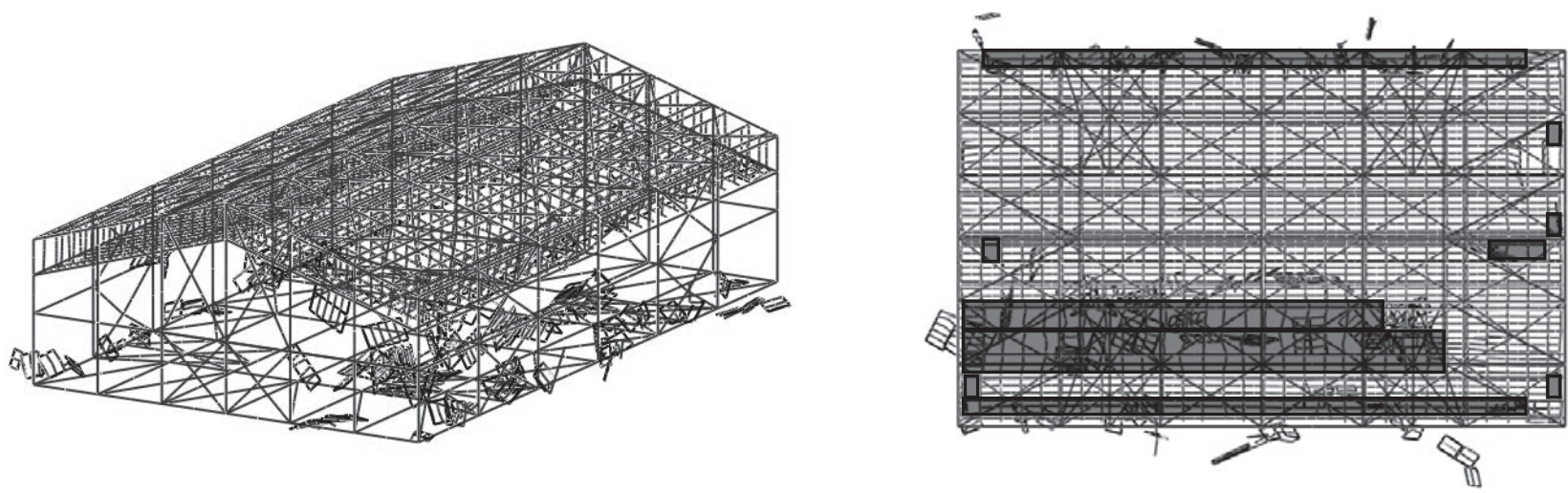

(d) After $2^{\text {nd }}$ peak during $2^{\text {nd }}$ excitation

Collapsed area of ceilings

Fig. 20 Collapse sequence of ceilings

スを設けた。解析には，脱落被害再現実験で K-NET 仙台波を $50 \%$ に縮小して加振した際に震動台上で観測された，桁行，梁間，上下
の 3 軸方向の加速度（以下, 台上加速度と表記）を用いた. 図 11 に

1 回目と 2 回目の加振時に計測された台上加速度を $5 \mathrm{~s}$ の間隔を設 
けて結合した波形を示す，実験では試験体が震動台に載りきらず張 り出していたため, 図 12 に示すように震動台上にある基礎梁のみ を固定して加振を行った。 そこで, 解析でも同様に震動台上の基礎 梁の節点のみを完全拘束し，この部分に図 11 の計 $155 \mathrm{~s}$ の波形を 入力した. 解析時間は, Intel Corei7-4790K CPU @ $4.00 \mathrm{GHz}$, メ モリ $16.0 \mathrm{~GB}$ で約 86 時間であった。

\section{5. 解析結果}

\section{1 屋根面における応答加速度および変位の比較}

図 12 の X4-Y3 通りの屋根面における桁行，梁間，上下方向の 1 回目加振時の応答加速度の時刻歴を図 13 図 15 に, 加速度応答ス ペクトルを図 16 に示す。応答加速度の時刻歴は，15-25 $\mathrm{s}$ の第 1 ピ 一ク時および 60-75 s の第 2 ピーク時を抽出して示している.なお, 実験の加速度データには, 試験体の大梁上に取り付けられた屋根荷 重を表現するための錘が，実験時に天井を支える母屋材に接触した 際に発生した衝撃を加速度センサーが拾ったためと思われる，短周 期成分が卓越した波形が確認された。そこで，加振による躯体の振 動のみを観察するため，実験結果には $10 \mathrm{~Hz}$ のローパスフィルタ （LPF）をかけて衝撃波の影響を取り除いた。全体的な傾向を見る と，桁行方向については解析結果と実験結果の間に多少の差異が認 められるものの，梁間方向と上下方向については良好に一致してい る. 図 16 の加速度応答スペクトルでも, 梁間・上下方向は実験結果 と良好に一致しているのに対し，桁行方向は実験結果と形状が多少 異なる結果となった。 2 回目加振時の応答加速度の時刻歴および加 速度応答スペクトルについても同様の傾向が確認された.

次に, 図 12 の X4-Y4 通りの屋根面における桁行, 梁間, 上下方 向の 1 回目加振時の応答変位の時刻歴を図 17 図 19 に示す.ここ でも，15-25 s の第 1 ピーク時および 60-75 s の第 2 ピーク時の時 刻歴を抽出して示している。これらの図より，梁間・上下方向の波 形は実験結果と良好に一致していることが確認できる．また，桁行 方向に関しては実験結果より振幅が多少小さいものの, 位相は良好 に一致していることが分かる. 2 回目加振時の応答変位の時刻歴に ついても同様の傾向が確認された.

\section{2 天井の落下状況およびその要因}

図 20 に解析により得られた天井の落下状況を示寸.また図 21 に は，図に示す時間帯におけるクリップ要素の脱落箇所を黒い点で示 す．本解析では，全ての天井落下がクリップの脱落を要因として発 生していた.

1 回目加振時の第 1 ピーク時には, 図 20 (a)に示すように梁間面 の壁との接触部で野縁とせっこうボードが一体化して落下している. 解析モデルでは梁間面の壁と天井間のクリアランスが $1 \mathrm{~mm}$ と容易 に接触する距離にあるため, 第 1 ピーク時には壁とせっこうボード が接触し，天井面に壁からの反力が作用している，その際，梁間面 の壁と天井が斜めに接触するため, 反力の天井面法線方向分力によ ってクリップに引張力が作用し引き抜かれている. クリップが脱落 すると，せっこうボードは野縁に支えられたまま宙吊りになるが， それを支える野縁ジョイントがせっこうボードの重量に耐えきれず 脱落するため，野縁とせっこうボードが一体化して落下したと考え られる. また図 21(a)より, 多くのクリップ要素が早い段階で脱落し ていることが確認できる．全体の $1 / 4$ 程度のクリップ要素がこの時

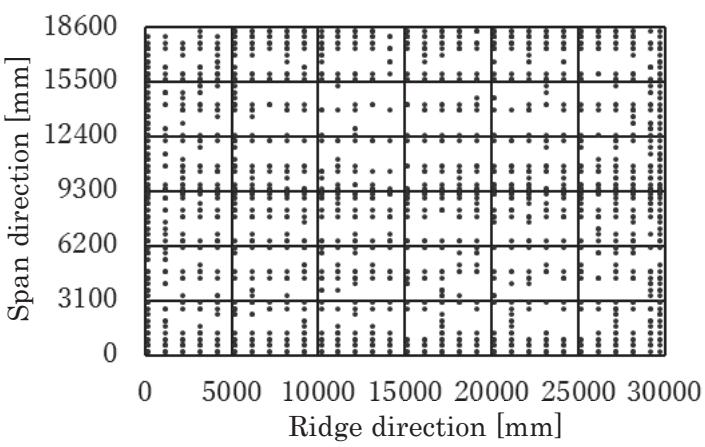

(a) $0-30 \mathrm{~s}$

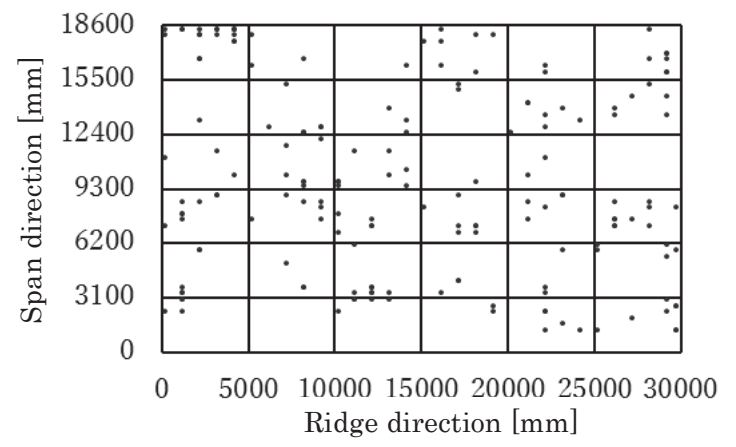

(b) $30-75 \mathrm{~s}$

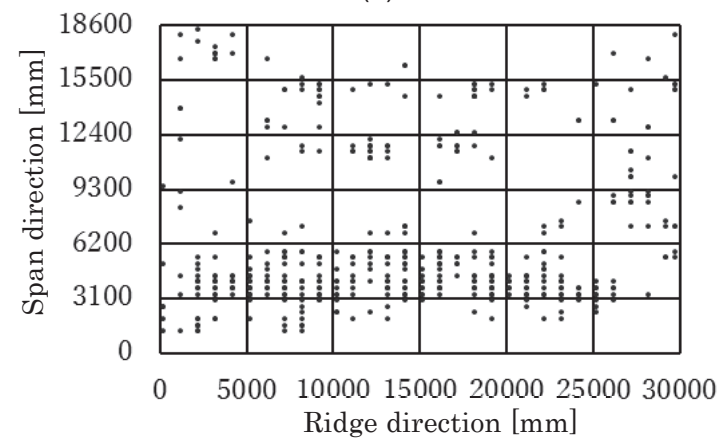

(c) $75-110 \mathrm{~s}$

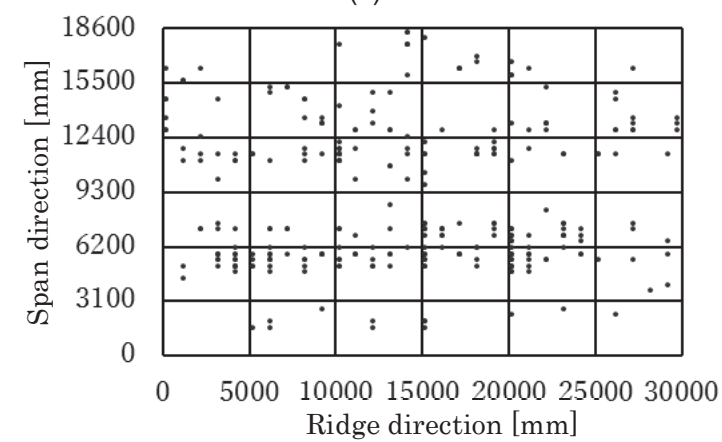

(d) $110-155 \mathrm{~s}$

- : Detached clip element

Fig. 21 Location of detached clip elements during each time zone

間帯に脱落していた。これは, せっこうボードが梁間面の壁に接触 した際に，壁からの反力と天井面頂部の慣性力により頂部が持ち上 がるモーメントが発生し, さらに吊りボルトが座屈することで天井 面の上下方向の振動が増大し, クリップに大きな引抜き力が発生し たためと考えられる.

1 回目加振時の第 2 ピークでは, 図 20(b)に示すように第 1 ピー クと同じ状況で壁との接触部で天井落下が確認できるが，それ以外 の範囲では落下が見られない。また, 梁間面の壁際の天井が落下し 


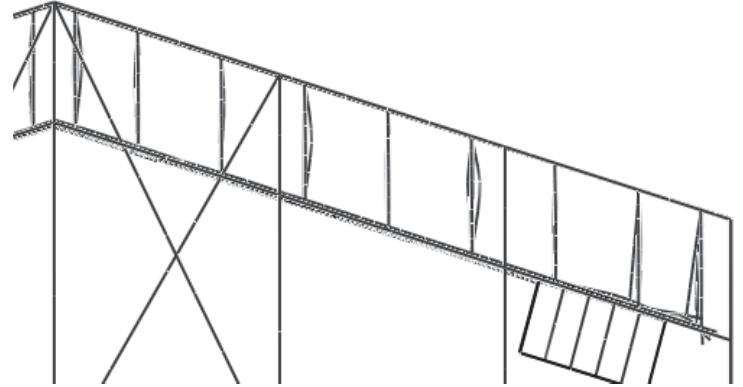

Fig. 22 Buckling occurred in hanging bolts (99.6 s)

たことにより壁との間に大きな隙間ができたため，天井が梁間方向 に大きく振れる挙動が見られた。壁との接触がなく, 天井面を持ち 上げるモーメントが発生しないため, 図 21(b)に示すように第 1 ピ ークよりはクリップの脱落箇所は少ない.しかし, 残されたクリッ プに対しては，第 1 ピーク時に脱落したクリップの負担荷重が再分 配され，そこへさらに地震動が加わった。 そのため, 一定数のクリ ップが脱落している.

2 回目加振時の第 1 ピークでは, 梁間方向 $3,100 \mathrm{~mm}$ の辺りで天 井の連鎖的な落下が確認できる. 1 回目加振終了時にはすでに多く のクリップが脱落しており，そのため残存するクリップには大きな 負荷が作用している。 そこへ 2 回目加振の強い振動が加わることに より一部のクリップが脱落，そして負担荷重の再配分によりさらな る脱落が発生し, 結果的に天井の落下が連鎖的に発生したと考えら れる.この時にも，図 22 に示すように 1 回目加振第 1 ピーク時に 見られたような吊りボルトが座屈する現象が見られた。クリップの 脱落箇所も図 $21(\mathrm{c})$ に示寸ように天井の落下範囲に集中しているこ とが確認できる。

2 回目加振時の第 2 ピークでは, 第 1 ピーク時に落下した天井の 近傍でさらに別の天井が落下している。ここでも，荷重の再分配に より負担が増大したクリップに地震動による慣性力が加わることで, 脱落が進んだものと考えられる.

本解析では，せっこうボードが壁に接触した際に壁からの反力が 発生している点，それにより天井頂部で持ち上げモーメントが発生 し多くのクリップが脱落している点，さらには荷重再配分による負 担増に起因して天井が連鎖的に落下している点等，実験より考察さ れた脱落被害メカニズム 8 )が概ね再現できているといえる。しかし ながら, 天井面頂部で集中的に天井が落下した実験結果とは一致し ない結果となった。この要因は，解析では 1 回目加振時に梁間面の 壁との接触部で多くの天井が落下したため，その後に頂部を持ち上 げるモーメントが発生せず, 頂部における損傷が小さくなったため と考えられる.

\section{6. 最後に}

本稿では，吊り天井付き体育館モデルを構築し，ASI-Gauss 法を 用いて連続加振解析を実施した。その結果，屋根面の応答は実験結 果と良好に一致した。 また， E一ディフェンスによる実験での天井 落下要因の一つとされた, 吊りボルトの座屈現象を確認することが できた，さらに，天井落下位置は多少異なるものの，脱落被害メカ ニズムは概ね再現できたと考えられる。ほぼ同じ波形を入力した 1
回目と 2 回目加振での解析結果が異なることから，加振前のクリッ プや吊りボルトの状況がその後の天井の挙動に大きな影響を与える ことが確認された．具体的には，クリップが加振前から既に脱落し ている場合には，その周辺箇所で荷重負担が増加しクリップの脱落 がさらに進行すること，吊りボルトが座屈を起こすとその下部のク リップは脱落が進行しやすくなるなどの点が確認された．今後は， 解析の再現性を向上させるために, クリップやハンガーの滑り現象 の考慮, 野縁ジョイント他の各要素の脱落条件の高精度化について 検討していく予定である.

\section{謝辞}

本研究は，防災科学技術研究所の数值震動台研究開発分科会（委 員長：大崎純（京都大学））設備WG の研究プロジェクトとして行 ったものである. また, 元筑波大院生の山本 卓也氏（現東芝ライフ スタイル (株)）から本研究に対して多大なる貢献を受けた。ここに 記して謝意を表する。

\section{参考文献}

1) National Institute for Land and Infrastructure Management \& Building Research Institute: Report on Field Surveys and Subsequent Investigations of Building Damage Following the 2011 Off the Pacific Coast of Tohoku Earthquake, 2012. 3 (in Japanese) 国土交通省国土技術政策総合研究所：独立行政法人建築研究所 : 平成 23 年 （2011 年）東北地方太平洋沖地震被害調査報告書, 2012. 3

2) Building Research Institute: Quick Report on Field Surveys and Subsequent Investigations of Building Damage Following the 2016 Kumamoto Earthquake, 2016. 9 (in Japanese) 国立研究開発法人 建築研究所：平成 28 年(2016 年)熊本地震建築物被害調 査報告（速報），2016.9

3) National Institute for Land and Infrastructure Management: Decree on Revision of Building Standards Law, No. 217, 2013 (in Japanese) 国土交通省：建築基準法施行令の一部を改正する政令, 政令第 217 号, 2013

4) National Institute for Land and Infrastructure Management: On Specific Ceiling and Its Structurally Safe Measures, Notice by NILIM, No. 771, 2013 (in Japanese) 国土交通省：特定天井および特定天井の構造耐力上安全な構造方法を定め る件，国土交通省告示第 771 号, 2013

5) National Institute for Land and Infrastructure Management: On Technical Standards of Ceiling Collapse Countermeasures in Buildings, 2013. 9 (in Japanese)

国土交通省：建築物における天井脱落対策に係る技術基準の解説, 2013. 9

6) Ministry of Science and Technology: Report on Field Surveys of Seismic Renovations in Public School Facilities, 2015. 6 (in Japanese) 文部科学省：公立学校施設の耐震改修状況調査の結果について, 2015. 6

7) Ministry of Science and Technology: Guidebook on Seismic Renovation of Non-Structural Components in School Facilities (revised version), 2015. 3 (in Japanese)

文部科学省：学校施設の非構造部材の耐震化ガイドブック(改訂版), 2015. 3

8) Sasaki, T. et al., Collapse Mechanism of Wide-area Suspended Ceiling System Based on E-Defense Full-scale Shake Table Experiments, Shake Table Experiments on Non-seismic Suspended Ceiling and Seismically Designed Suspended Ceiling, 2015. 2 (in Japanese) 佐々木智大，青井 淳，田川浩之，梶原浩一，荒井智一，金井貴浩，高岡昌 史，岩下裕樹，吉澤睦博，壁谷澤寿海，清家 剛，山田 哲，福山 洋，太田 勤, 江口 亨, 伊山 潤, 石原 直, 磯部大吾郎: 大規模空間吊り天井の脱落 被害メカニズム解明のための $\mathrm{E}$ ーディフェンス加振実験 報告書 一大規 模空間吊り天井の脱落被害再現実験および而震吊り天井の耐震余裕度検証 実験一, 2015. 2

9) Isobe, D. and Lynn, K.M.: Structural Collapse Analysis of Steel Framed 
Structure due to Aircraft Collision, Journal of Structural and Construction Engineering (Transactions of AIJ), No.579, pp.39-46, 2004. 5 (in Japanese)

磯部大吾郎, チョウミョウリン: 飛行機の衝突に伴う骨組鋼構造の崩壊解 析, 日本建築学会構造系論文集, 第 579 号, pp39-46, 2004. 5

10) Japan Structural Consultants Association: Handbook on Anti-Seismic Structural Design, Ohm-sha, 2008 (in Japanese)

社団法人 日本建築構造技術者協会: 而震構造設計ハンドブック，オーム 社, 2008

11) Chinzei, H. et al: Pull Out Experiment and Collapse Mechanism of Tapping Screw Connection Study on Mechanical Characteristic of Tapping Screw: Connection in Nonstructural Components Part1, Summaries of Technical Papers of Annual Meeting, Architectural Institute of Japan, B-1, pp. 891-892, 2015. 9 (in Japanese)
鎮西 宏, 元結正次郎, 天野聡志, 佐々木康人, 佐藤幸博, 田原健一：頭抜 け試験と崩壊メカニズム 非構造部材におけるビス接合部の力学的性状に 関する研究 その 1, 日本建築学会大会学術講演梗概集, B-1, pp. 891-892, 2015. 9

12) Sugiyama, T. et al: Shear Tests of Screwed Joint between Ceiling Joist and Plaster Board of Conventional Type Ceiling Part 1: Test Plan and Results of Element Tests, Summaries of Technical Papers of Annual Meeting, Architectural Institute of Japan, B-1, pp. 871-872, 2010. 7 (in Japanese)

杉山達也, 柏崎玩也, 野曽原瑞樹, 貫井 泰, 鈴木 篤: 在来工法天井の下地 ボードと野縁のビス止め接合部のせん断試験：その 1:試験計画および要 素試験の結果, 日本建築学会大会学術講演梗概集, B-1, pp. 871-872, 2010. 7 


\title{
COLLAPSE SIMULATION OF WIDE-AREA SUSPENDED CEILING SYSTEM USING FINITE ELEMENT METHOD
}

\author{
Daigoro ISOBE* , Takashi FUJIWARA **, Takuzo YAMASHITA***, \\ Hiroyuki TAGAWA **** and Tomohiro SASAKI**** \\ * Prof., Univ. of Tsukuba, Dr.Eng. \\ ** Former Grad. Student, Univ. of Tsukuba, M.Eng. (currently Samsung Japan Corporation) \\ ****** Chief Researcher, NIED, Dr.Eng. \\ ***** Former Chief Researcher, NIED, Dr.Eng. (currently Tech. Res. Inst. of Obayashi Co.)
}

Many ceiling collapse damages were observed in wide-area structures such as gymnasiums during the 2011 Great East-Japan Earthquake and the 2016 Kumamoto Earthquake. The prevention of ceiling collapse phenomena is an important issue not only to save people's lives, but to keep these facilities to be safely used as shelters after earthquakes.

In this paper, a numerical analysis to simulate the ceiling collapse in a full-scale gymnasium specimen, which was tested at the E-Defense shaking table facility in 2014, was conducted. A numerical model consisted of steel structural frames and suspended ceilings were constructed. All the members were modeled using linear Timoshenko beam elements and the adaptively shifted integration (ASI) - Gauss code was applied. Hangers and hanging bolts were modeled in one piece. The plaster boards were assumed as rigid in out of plane direction and only the mass of rock wool boards was considered. Their strength were neglected. Clips and screws were modeled with minute, small elements. Each plaster board was modeled separately to consider local contact between plaster boards, which was simulated by modeling the screws slightly apart. Elasto-plastic buckling of braces and hanging bolts were considered by modeling them with eight beam elements each and two hinge elements on both ends. The clips connecting ceiling joists and ceiling joist receivers are small and delicate components that may be detached during repeated excitation. Once there is a local detachment of clips, a change in the load distribution may cause a chain reaction of detachments, which ends in a drop of plaster boards. Furthermore, the detachments of hanging bolts that are connected to the structural members composing the roof, and failure of screws on plaster boards are assumed to be other main causes of the ceiling collapse. The results of some preliminary tests conducted to see the actual strength of these components are implemented in the analysis for criteria.

The numerical result was validated by the experimental result, which was performed at the E-Defense under an input of two continuous K-NET Sendai 50\% waves. The acceleration responses, the spectrum and the displacement responses obtained on the roof matched well with the experimental result. According to the results, the plaster boards near walls pattered down occasionally at the first peak of the first wave. These were due to detachment of clips and screws caused by collisions to the walls. Then, the clips near roof top began to get loose due to buckling of hanging bolts caused by vertical excitation, which ends, at the first peak of the second wave, in drop of plaster boards in a wide range. The numerical result had shown the collapse of the ceilings progressed owing to the detachment of clips that connected the ceiling joists to the ceiling joist receivers, which eventually led to a large-scale collapse of the ceilings. 